\title{
In vivo antiplasmodial activities of Nauclea latifolia
}

\author{
Ette Okon Ettebong1', Ubulom P.M. Edwin², Ekpenyong C. Edet ${ }^{3}$,Ekong U. Samuel ${ }^{2}$, Akpan O. Ezekiel ${ }^{1}$ \\ Tambari V. Dornu²
}

${ }^{1}$ Department of Pharmacology and Toxicology, Faculty of Pharmacy, University of Uyo, Nigeria, ${ }^{2}$ Pharmaceutical Microbiology and Parasitology Unit, Department of Pharmaceutics and Pharmaceutical Technology, Faculty of Pharmacy, University of Uyo, Nigeria, ${ }^{3}$ Department of Physiology, Faculty of Basic Medical Sciences, College of Health Sciences, University of Uyo, Nigeria

\section{A B S T R A C T}

Background: The plant Nauclea latifolia is widely used in the southern parts of Nigeria for the treatment of malaria. Malaria is the number one killer disease in Nigeria. WHO reports that malaria continues to cause approximately 207 million cases of infection around the world and kills yearly about 627,000 people. It still kills a child somewhere in the world every minute. The study was aimed at evaluating the in vivo antiplasmodial activities of the extract and fractions (n-hexane, chloroform, ethyl acetate, butanol, aqueous) of the stembark in Plasmodium berghei berghei infected mice. Materials and Methods: Through oral administration of the extract $(100,200$ and $300 \mathrm{mg} / \mathrm{kg})$ and fractions $(200 \mathrm{mg} / \mathrm{kg})$, antiplasmodial activities were screened using 4-day suppressive, 7-day curative and repository tests. Significance was determined using ANOVA followed by Tukey-Kramer multiple comparison post- test using Graphpad Instat 3.10. A probability level of less than $5 \%$ was considered significant. Results: The extract exhibited significant dose-dependent antiplasmodial activity in the suppressive and repository tests. A significant $(p<0.05-0.001)$ dose-dependent reduction in parasitaemia in extract-treated groups in curative test was also observed. The aqueous fraction had the highest percentage chemosuppressive effect $(67.71 \%)$. The extract also dose-dependently increased the survival days of the infected mice. The preliminary phytochemical investigation showed the presence of alkaloids, saponins, tannins, flavonoids and cardiac glycosides. Conclusion: This result confirmed the ethnobotanical use of the plant as malarial remedy and calls for further investigation of its phytochemical components and its antimalarial potentials.

Key words: Antiplasmodial, Extract, Parasitaemia, Plasmodium berghei berghei
Access this article online

Website:

http://nepjol.info/index.php/AJMS

DOI: 10.3126/ajms.v6i3.11361

\section{INTRODUCTION}

Nauclea latifolia, known commonly as African peach, is a straggling shrub with rounded ovate leaves. ${ }^{1}$ This plant is about $10 \mathrm{ft}$ high with flowers and has fruits which are edible, but not appealing. It is a native of Africa but is widely distributed throughout the forest and tropical forests of Benin, Burkina Faso, Cameroon, Democratic Republic of Congo, Ghana and Nigeria. ${ }^{2}$ Among the Ibibios of South-South Nigeria, the stembark either as an infusion or decoction is used as antimalarial, antipyretic and aphrodisiac. The rootbark is used as tonic, antipyretic, antidepressant and analgesic. The leaf has the potential to relieve dysentery and diarrhorea. ${ }^{1}$ Different parts of the plant including the inner bark, stem, sap, roots, fruits and bark of root have been used in the treatment of sleeping sickness, cough, febrile conditions, thrush, jaundice, piles, stomach and menstrual disorders as well as sores. ${ }^{3}$ In Guinea, West Africa, the root is used as tonic, stimulant and a restorative. ${ }^{2}$ Nauclea latifolia is reported to contain monoterpene indole alkaloids and the major ones being naucleamides A-E such as tetrahydro- $\beta-$ carboline monoterpene alkaloid glycosides, naucleaorine and epimethoxy-naucleaorine, isolated by chloroform from the dried stem of $N$. latifolia. ${ }^{4}$ Scientific reports show that it is antihypertensive and laxative, ${ }^{5,6}$ anti-inflammatory, analgesic, antipyretic; ${ }^{7}$ antidepressant, myorelaxant and anxiolytic, ${ }^{8}$ antimicrobial, ${ }^{9,10}$ antiplasmodial in vitro, ${ }^{11}$ 
anthelmenthic, ${ }^{12,13}$ and antidiabetic. ${ }^{14}$ Literature from previous studies confirms the presence of tannins, alkaloids, glycosides and saponins in this plant. ${ }^{15}$ Much of the antiplasmodial work done on this plant is in vitro than in vivo. The aim of this study was to evaluate its in vivo antiplasmodial properties and to call the attention of the scientific world to a plant with such great but neglected potentials.

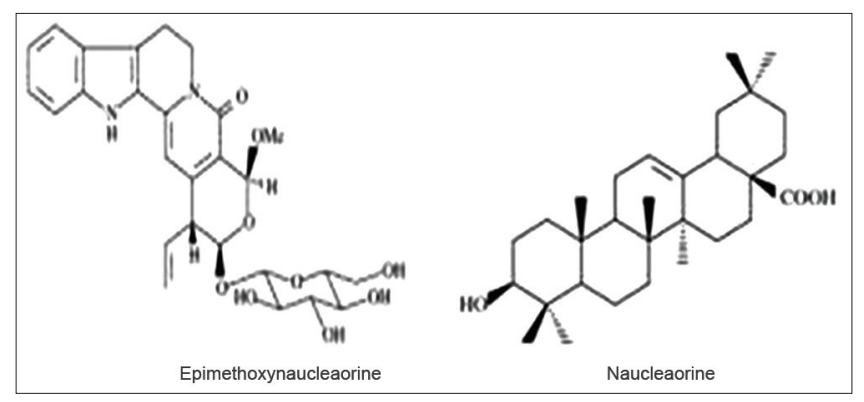

\section{MATERIALS AND METHODS}

\section{Plant materials}

The plant material of Nauclea latifolia was collected in September 2011 from Uyo, Akwa Ibom State, SouthSouth Nigeria. The plant was identified and authenticated by Dr. (Mrs.) Margaret Bassey (a plant Taxonomist) in the Department of Botany and Ecological Studies, University of Uyo, where a voucher specimen with herbarium number UUH67G was deposited. The plant material was air-dried and then oven-dried at reduced temperature $35+2^{\circ} \mathrm{C}$. It was thereafter ground into powder and cold-macerated in $70 \%$ ethanol for $72 \mathrm{~h}$, and filtered. The filtrate was dried in vacuo using the rotary evaporator. $30 \mathrm{~g}$ of the dried extract was partitioned successively using various solvents such as n-hexane, chloroform, ethyl acetate, butanol and water to obtain their respective fractions. This partitioning yielded n-hexane (1.0 g), chloroform (2.1 g), ethyl acetate (1.6 g), butanol $(3.2 \mathrm{~g})$ and water $(5.0 \mathrm{~g})$ respectively. The crude extract and fractions were stored in a refrigerator at $-4^{\circ} \mathrm{C}$ until required for use.

\section{Phytochemical screening}

The extract was screened for bioactive ingredients such as saponins, alkaloids, tannins, phlobotannins, flavonoids, anthraquinones, and cardiac glycosides as per the method described by Evans. ${ }^{16}$

\section{Animal Stock}

Adult albino mice (22-30 g) were obtained from the Animal House of the University of Jos, Jos, Plateau State and maintained in the University of Uyo Animal House and fed with growers pellet Feed (Bendel Feeds and Flour mills Ltd, Edo State) with water given ad libitum. Approval for the use of animals in the study was obtained from the
Animal Ethics Committee, Faculty of Pharmacy, University of Uyo, Uyo, Akwa Ibom State, Nigeria.

\section{Micro-organisms}

A chloroquine- sensitive strain of $P$. berghei berghei (NK-65) was obtained from National Institute of Medical Research (NIMER) in Lagos and maintained by subpassage in mice.

\section{Inoculum preparation}

The parasitized blood donor with high parasitaemia was obtained by first anaesthetizing the mouse with chloroform, and through cardiac puncture blood was collected using sterile syringe into sterile heparinised bottles. The percentage parasitaemia was determined by counting the number of parasitized red blood cells against the total number of red blood cells. The desired volume of blood then obtained from the donor mouse was suitably diluted with sterile normal saline so that the final inoculum $(0.2 \mathrm{ml})$ for each mouse contained the required number of parasitized red blood cells (that is $1.0 \times 10^{7}$ parasitized red blood cells). Therefore, the $0.2 \mathrm{ml}$ of the final inoculum contained $1 \times 10^{7}$ parasitized red blood cells which is the standard inoculum for the infection of a single mouse. ${ }^{17,18}$

\section{Drug administration}

Drugs (chloroquine and pyrimethamine), extract and all fractions used used in the current study were administered through the oral route using stainless metallic feeding cannula.

\section{Acute toxicity studies}

Acute toxicity study was carried out to determine the median lethal dose $\left(\mathrm{LD}_{50}\right)$ using the modified method of Miller and Tainter as described by Jigam et al. ${ }^{19,20}$

\section{Antiplasmodial activities of the extract}

Suppressive activity on early infection (4 - day test)

To determine the suppressive activity of the extract, the method earlier described with modifications was adopted. ${ }^{21}$ The mice were each inoculated on the first day (day 0), intraperitoneally with $0.2 \mathrm{ml}$ of infected blood containing about $1 \times 10^{7} P$. berghei berghei parasitized erythrocytes. The animals were then randomly divided into six groups of six animals each. After ten minutes, the mice in the first group were orally administered with $10 \mathrm{ml} / \mathrm{kg}$ of distilled water and served as control. Groups 2, 3, and 4 received 100,200 and $300 \mathrm{mg} / \mathrm{kg}$ of the extract orally. Group 5 received chloroquine $5 \mathrm{mg} / \mathrm{kg} /$ day as positive control while group 6 animals were administered with $200 \mathrm{mg} / \mathrm{kg}$ of extract conjointly with chloroquine $5 \mathrm{mg} / \mathrm{kg} /$ day. The administration of extract and drug was continued daily for 4 days (D0 - D3) between $8.00 \mathrm{am}$ and $9.00 \mathrm{am}$. On the fifth day (D4) thin blood films were made from 
tail blood obtained from each mouse. The films were thereafter stained with Leishman's stain to reveal parasitized erythrocytes. The percentage parasitaemia was obtained by counting the number of parasitized red blood cells out of 500 erythrocytes in random fields of the microscope.

$\%$ Parasitaemia $=\frac{\text { No. of parasitized RBC }}{\text { Total No. of RBC counted }} \times 100$

Average percentage chemosuppression was calculated as

$100\left(\frac{\mathrm{A}-\mathrm{B}}{\mathrm{A}}\right)$

Where, $\mathrm{A}$ is the average percentage parasitaemia in negative control group and B, average percentage parasitaemia in the test group.

\section{Repository/Prophylactic Activity}

The methods earlier described with slight modifications were used to assess the prophylactic activity of the extract. ${ }^{21,22}$ Mice were divided randomly into 6 groups of six animals each. Group 1 animals received distilled water $10 \mathrm{ml} / \mathrm{kg}$. Groups 2, 3 and 4 were administered with 100,200 and $300 \mathrm{mg} / \mathrm{kg}$ of the extract orally. Group 5 animals served as positive control and were administered with $1.2 \mathrm{mg} / \mathrm{mg} /$ day of pyrimethamine. Group 6 animals received $200 \mathrm{mg} / \mathrm{kg}$ of the extract and Pyrimethamine $(1.2 \mathrm{mg} / \mathrm{kg} / \mathrm{day})$. All the groups were treated for three consecutive days $\left(\mathrm{D}_{0}-\mathrm{D}_{2}\right)$ and on day $4\left(\mathrm{D}_{3}\right)$, the mice were intraperitorneally injected with $1.2 \mathrm{ml}$ of infected blood that contained $1 \times 10^{7}$ Plasmodium berghei berghei parasitized red blood cells (RBCs). The level of parasitaemia was assessed using thin films obtained from tail blood of each mouse $72 \mathrm{~h}$ after parasite inoculation. Percentage parasitaemia and the average chemosuppression were calculated as stated above.

Evaluation of antiplasmodial activity on established infection (Curative or Rane Test)

To assess the schizonticidal activity of the extract during established infection, the methods earlier described and modified were used. ${ }^{21,22}$ Thirty-six mice were inoculated intraperitoneally with standard innoculum of $1 \times 10^{7}$ Plasmodium berghei parasitized red blood cells on the first day $\left(\mathrm{D}_{0}\right) .72 \mathrm{~h}$ later, the mice were randomized into 6 groups of six animals each. Group 1 received $10 \mathrm{ml} / \mathrm{kg}$ of distilled water. Groups 2, 3 and 4 animals were administered with 100,200 and $300 \mathrm{mg} / \mathrm{kg} /$ day of the extract orally. Group 5 animals were administered with $5.0 \mathrm{mg} / \mathrm{kg} /$ day of chloroquine. Group 6 animals received $200 \mathrm{mg} / \mathrm{kg}$ of extract along with $5 \mathrm{mg} / \mathrm{kg} /$ day of chloroquine. All the drugs were administered to the animals once daily for 5 days. Tail blood samples from each mouse was collected daily for 5 days, stained with Leishman's stain and thin films prepared were used to monitor the level of parasitaemia.
The Mean Survival Time (MST) of each group was determined over a period of 30 days $\left(\mathrm{D}_{0}-\mathrm{D}_{29}\right)$.

$$
\text { MST }=\frac{\text { No. of days survived }}{\text { Total No. of days (30) }} \times 100
$$

\section{Suppressive activity on fractions (4-day test)}

Using the method earlier described ${ }^{21}$ various fractions of Nauclea latifolia (n-hexane, chloroform, ethylacetate, butanol, and aqueous) were administered orally at the dose of $200 \mathrm{mg} / \mathrm{kg} /$ day to different groups of six animals each 30 min after intraperitoneal injection of $0.2 \mathrm{ml}$ of infected blood containing about $1 \times 10^{7} \mathrm{P}$. berghei berhei. The negative control group received $10 \mathrm{ml} / \mathrm{kg}$ of distilled water. The administration of fraction/distilled water was continued for 4 days $\left(D_{0}-D_{3}\right)$. Thin films were prepared from tail blood of each mouse on the fifth day and the level of parasitaemia was determined by counting the number of parasitized red blood cells out of 500 RBCs in random field of the microscope. The average percentage chemosuppression was calculated as stated above.

\section{Statistical analysis}

Results were expressed as multiple comparisons of Mean + SEM. Significance was determined using One-way Analysis of Variance (ANOVA) followed by Tukey-Kramer multiple comparison post- test using Graphpad Instat 3.10. A probability level of less than $5 \%$ was considered significant.

\section{RESULTS}

Phytochemical studies: Preliminary phytochemical studies showed the presence of alkaloids, saponins, tannins, flavonoids and cardiac glycosides.

Acute toxicity studies: The median lethal dose (LD50) was determined to be $1,183 \pm 0.01 \mathrm{mg} / \mathrm{kg}$.

\section{Antiplasmodial activities}

Suppressive activity: The extract exhibited significant $(p<0.001)$ dose-dependent antiplasmodial activity in the suppressive test when compared with control (Table 1).

Repository/prophylactic test. A significant $(\mathrm{p}<0.001)$ dose-dependent reduction in parasitaemia in extract-treated groups was observed relative to control (Table 2).

Curative or Rane test. The extract-treated groups showed a significant $(p<0.05-0.001)$ dose-dependent reduction in parasitaemia compared to control (Figure 1).

Suppressive activity on fractions: The fractions exhibited various degrees of chemosuppressive effects. However, aqueous fraction had the highest percentage 


\begin{tabular}{|c|c|c|c|}
\hline Drug extract & $\begin{array}{c}\text { Dose } \\
\text { (mg/kg) }\end{array}$ & Praasitaemia & $\begin{array}{c}\% \\
\text { Chemosuppression }\end{array}$ \\
\hline Control & 10 & $71.00 \pm 1.83$ & - \\
\hline \multirow[t]{3}{*}{ Extract } & 100 & $41.67 \pm 2.43^{a}$ & 41.31 \\
\hline & 200 & $32.33 \pm 2.01^{\mathrm{a}}$ & 54.46 \\
\hline & 300 & $25.67 \pm 2.69^{a}$ & 63.84 \\
\hline Chlorquine & 5.0 & $0.00 \pm 0.00$ & 100.00 \\
\hline Chloroquine+extract & $5.0+200$ & $0.00 \pm 0.00$ & 100.00 \\
\hline
\end{tabular}

Values are expressed as mean $\pm S E M$. Significance relative to control ${ }^{a} p<0.001, n=6$

\begin{tabular}{|c|c|c|c|}
\hline Drug extract & $\begin{array}{c}\text { Dose } \\
(\mathrm{mg} / \mathrm{kg})\end{array}$ & Parasitaemia & $\begin{array}{c}\% \\
\text { Chemosuppression }\end{array}$ \\
\hline Control & $10 \mathrm{ml}$ & $78.00 \pm 3.29^{a}$ & - \\
\hline \multirow[t]{3}{*}{ Extract } & 100 & $59.67 \pm 2.74^{a}$ & 23.50 \\
\hline & 200 & $43.00 \pm 1.67^{a}$ & 44.87 \\
\hline & 300 & $39.33 \pm 2.57^{a}$ & 49.58 \\
\hline Pyrimethamine & 1.2 & $28.00 \pm 2.92^{\mathrm{a}}$ & 64.10 \\
\hline $\begin{array}{l}\text { Pyprimethamine+ } \\
\text { extract }\end{array}$ & $1.2+200$ & $23.67 \pm 2.20^{\mathrm{a}}$ & 56.83 \\
\hline
\end{tabular}

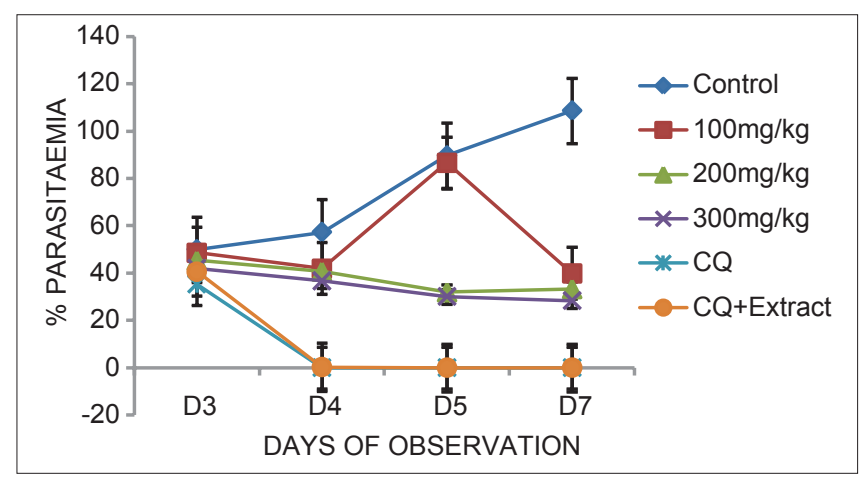

Figure 1: Effect of $N$. latifoliaon established infection (Curative test)

chemosuppressive effect (67.71\%) while butanol fraction had the least $(15.68 \%)$ (Table 3).

Mean survival time: The mean survival times of extracttreated groups of mice increased dose-dependently and significantly $(\mathrm{p}<0.05-0.001)$ with the longest being 22.00 days observed with the highest dose $(300 \mathrm{mg} / \mathrm{kg})$ when compared to control but shorter when compared with standard drug chloroquine (27.33 days) (Table 4).

\section{DISCUSSION}

The preliminary phytochemical screening of Nauclea latifolia, stembark showed the presence of alkaloids, saponins, flavonoids, cardiac glycosides and tannins. Alkaloids, saponins and flavonoids are suggested as being responsible for the antimalarial activities of the plant. These

\begin{tabular}{|c|c|c|c|}
\hline Drug/fractions & $\begin{array}{c}\text { Dose } \\
\text { (mg/kg) }\end{array}$ & Parasitaemia & $\begin{array}{c}\% \\
\text { Chemosuppression }\end{array}$ \\
\hline Distilled water & 100 & $74.33 \pm 2.37$ & - \\
\hline Aqueous & 200 & $24.00 \pm 1.46^{b}$ & 67.71 \\
\hline n-hexane & 200 & $51.33 \pm 1.92$ & 30.94 \\
\hline Chloroform & 200 & $34.00 \pm 1.42^{a}$ & 54.25 \\
\hline Ethyl acetate & 200 & $28.33 \pm 1.64^{b}$ & 61.88 \\
\hline Butanol & 200 & $62.67 \pm 2.85$ & 15.68 \\
\hline Chloroquine & 5.0 & $0.00 \pm 0.00^{c}$ & 100 \\
\hline
\end{tabular}

Values are expressed as mean \pm SEM. Significance relative to control $\mathrm{a} p<0.05 ;$ ${ }^{b} p<0.01 ;{ }^{c} p<0.001, n=6$

\section{Table 4: The mean survival time (MST) of} ethanolic extract of Nauclea latifolia

\begin{tabular}{lcc}
\hline Drug/extract & $\begin{array}{c}\text { Dose } \\
\mathbf{m g} / \mathbf{k g}\end{array}$ & $\begin{array}{c}\text { Mean survival } \\
\text { time (MST): Days }\end{array}$ \\
\hline Distilled water & $100 \mathrm{ml}$ & $13.33 \pm 0.21$ \\
Extract & 100 & $14.67 \pm 0.21$ \\
& 200 & $16.67 \pm 0.56^{\mathrm{b}}$ \\
Chloroquine+extract & 300 & $22.00 \pm 0.36^{\mathrm{b}}$ \\
Chloroquine & $5.0+200$ & $25.67 \pm 0.21^{\mathrm{b}}$ \\
\hline
\end{tabular}

Values are expressed as mean \pm SEM. Significance relative to control $\mathrm{a}<<0.05 ;$ ${ }^{b} \mathrm{p}<0.001, \mathrm{n}=6$

secondary metabolites could have elicited the observed antiplasmodial activity either singly or in synergy with each other. ${ }^{4}$ Alkaloids have been known to show antimalarial properties by blocking protein synthesis in Plasmodium falciparum. ${ }^{23}$ Saponin, flavonoids and tannins have been suggested to act as primary antioxidant or free radicals scavengers that can counteract the oxidative damage induced by the malaria parasite. ${ }^{24}$ It has been reported that extracts of Nauclea latifolia exhibited substantial antioxidant capacity. It is possible that the antioxidant activity might be due to the presence of vitamins. ${ }^{25}$ Lenucci et $a{ }^{26}$ however, have demonstrated that the antioxidant activity is likely to be due to the presence of ascorbic acid, tocopherol and pigments. It is also possible that the antioxidant activity of extracts might be due to the presence of polyphenols. ${ }^{27}$ The antioxidant property of this plant may represent yet another mechanism that contributes to its antiplasmodial activity. ${ }^{28}$ Flavonoids are known to chelate with nucleic acid base pairing of malarial parasite. ${ }^{29}$ Flavonoids have also been known to show significant antiparasitic activities against different strains of malaria, trypanosome and Leishmania. ${ }^{30-32}$

Aqueous extracts from stems and roots of N. latifolia have been tested in vitro in two Plasmodium falciparum strains, FcB1-Colombia (chloroquine resistant) and a Nigerian strain (chloroquine-resistant) and found to inhibit essentially the final developmental stages of the parasites. Two novel tetrahydro- $ß$-carboline monoterpene alkaloid 
glycosides, naucleaorine and epimethoxy-naucleaorine, isolated by chloroform from the dried stem of N. latifolia, strictosidine lactam, and oleanolic acid showed moderate in vitro activities against Plasmodium falciparum. ${ }^{4}$ The fact that aqueous fraction showed the highest chemosuppressive effect when compared with others suggests that the active ingredients of this plant responsible for its antimalarial activity may be localized here. The antiplasmodial activities of Nauclea latifolia extract and its fractions as observed in this study may, therefore, have resulted from one or more of these mechanisms.

Cloroquine has shown a greater chemosuppressive activity than the extract and fractions of Nauclea latifolia from this study, but it is no longer being used as an antimalarial agent in man because of resistance. The advantage that Nauclea latifolia has is that it is new, effective and with no known resistance.

In conclusion, the preliminary phytochemical screening of N. latifolia stembark extract showed the presence of alkaloids, saponins, tannins, cardiac glycosides and flavonoids. The antiplasmodial activities of this plant may be ascribed to these constituents and further investigation is necessary to isolate, screen and determine the antiplasmodial compounds as well as their mechanism(s) of action. This study has established that N. latifolia stembark extract obtained from South-South Nigeria, possesses antiplasmodial activities.

\section{ACKNOWLEDGEMENTS}

We acknowledge the technical assistance of Messrs Nsikan M. Udo, Susana Attah and Aniefiok Ukpong of the Department of Pharmacology and Toxicology, University of Uyo, Uyo.

\section{REFERENCES}

1. Etukudoh I. Ethnobotany: Conventional and Traditional uses of plants. Verdict Press, Uyo; 2003: 116 -117.

2. Lamidi ME. Quinovic acid glycosides from Nauclea diderichii. Planta Medica 1993; 61: 280 -281.

3. Odugbemi T. A Textbook of Medicinal Plants from Nigeria. University of Lagos Press, Lagos, Nigeria 2008 ISBN: 978-97848712-9-7: 542-612.

4. Shigemori H, Kyhta T, Ishiyama $H$, Morah $F$, Ohsaki $S$ and Kobayashi J. Naucleamides A-E, new monoterpene indole alkaloids from Nauclea latifolia. Chemical and Pharmaceutical Bulletin 2003; 51, 58-61.

5. Akpanabiatu MI, Umoh IB, Udosen EO, Udoh AE and Edet EE. Rat serum electrolytes, lipid profile and cardiovascular activity on Nauclea latifolia leaf extract administration. Indian Journal of Clinical Biochemistry 2005; 20: 29-34.

6. Nworgu ZM, Owokobi OJ and Alomah JE. Effect of the ethanolic extract of Nauclea latifolia on isolated uterus of non-pregnant rats. International Journal of Green Pharmacy 2010; 4: 48-53.

7. Abbah J, Amos S, Chindo B, Ngazal I, and Vongtau HO. Herbal Remedies for Malaria. Journal of Ethnopharmacology 2010; 127: 85-90.

8. Taiwe GS, Bum EN, Dimo T, Talla E and Weiss N. Antidepressant, myorelaxant and anti-anxiety-like effects of Nauclea latifolia smith (Rubiaceae) roots extract in murine models. International Journal of Pharmacolology 2010; 6: 364-371.

9. Deeni $Y$ and Hussain $\mathrm{H}$. Screening for antimicrobial activity and for alkaloids of Nauclea latifolia. Journal of Ethnopharmacology 1991; 35: 91- 96.

10. Okiei W, Ogunlesi M, Osibote EA, Bintu MK and Ademoye MA. Comparative studies of the antimicrobial activity of components of different polarities from the leaves of Nauclea latifolia. Research Journal of Medicinal Plants 2011; 5: 321-329.

11. Benoit-Vical $F$, Valentin A, Cournac V, Pelissier $Y$, Mallie $M$ and Bastide JM. In vitro antiplasmodial activity of stem and root extract of Nauclea latifolia S.M (Rubiaceae). Journal of Ethnopharmacology 1998; 61: 173-178.

12. Onyeyili PA, Nwosu CO, Amin JD and Jibike JI. Anthelmintic activity of crude aqueous extract of Nauclea latifolia stem bark against ovine nematodes. Fitoterapia 2001;72: 12-21.

13. Ademola I, Fagbemi BO, and Idowu SO. Anthelminthic efficacy of Nauclea latifolia extract against gastrointestinal nematodes of sheep: In vitro and in vivo studies'. African Journal of traditional complementary and alternative medicines. AJTCAM African Networks of Ethnomedicines 2006; 4: 148-156.

14. Abubakar G, Danladi AA, Sunday EA, and Sani I. Antidiabetic effect of Nauclea latifolia ethanolic leaf extract in streptozocininduced diabetic rats. African Journal of Complementary and alternative medicines. AJTCAM African Networks on Ethnomedicines 2008; 5: 201-208.

15. El-Mahmood AM, Doughari JH and Chagi FJ. Scientific Research and Essay 2008; 3(3): 102 -105.

16. Evans WC. Pharmacognosy, $16^{\text {th }}$ ed, Edinburgh, London, New York, Philadelphia St Louis Toronto; 2009:135-147.

17. Okokon JE, Ettebong EO, Udobang JA and Obot J. Antiplasmodial and antiulcer activities of Melanthera scandens. Asian Pacific Journal of Tropical Biomedicine 2012; 16-20.

18. Muthaura CN, Rukunga GM, Chhabra SC, Omar SA, Guantai AN and Gathirwa W. Antimalarial activity of some plants traditionally used in Meru district of Kenya. Phytotherapy Research 2007; 21: 860-867.

19. Jigam AA, Usman TA and Martins NE. In-vivo antimalarial and toxicological evaluation of Chrozophora senegalensis A. Juss (euphorbaceae) extracts. Journal of Applied Pharmaceutical Science 2011; 1(10): 90-94.

20. Nwafor PA, Ettebong EO, Umoh EE and Essien GE. Antiinflammatory and analgesic effects of ethanolic extracts of Carpolobia lutea leaves in mice. Nigerian Journal of Experimental and Applied Biology 2008; 9(2): 125-132.

21. Okokon JE, Ettebong EO and Bassey SA. In vivo antimalarial activity of ethanolic leaf extract of Stachytarpheta cayennensis. Indian Journal of Pharmacology 2008; 40 (3): 111-113.

22. Tekalign D, Yalemtsehay $M$, and Abebe A. In Vivo anti-malarial activities of Clerodendrum myricoides, Dodonea angustifolia and Aloe debrana against Plasmodium berghei. Ethiopian Journal of Health Development 2010; 24(1): 25-29.

23. Nergiz $C$ and Otles S. Chemical Composition of Nigella Sativa I. Seeds. Food Chemistry 1993; 48: 259-261.

24. David AF, Philip JR, Simon LC, Reto B, and Solomon N. Antimalarial drug discovery: efficacy models for compound screening. Nature Reviews Drug Discovery 2004; 3: 509-520.

25. Akadiri Y, Joachim G, Oussama G, Aziz H, Anne-Marie S, Zouhair 
T, Mansourou M, Kabirou M and Naim AK. Anti-hyperglycemic effects of three medicinal plants in diabetic pregnancy: modulation of $\mathrm{T}$ cell proliferation. BMC Complementary and Alternative Medicine 2013; 13:77 doi:10.1186/1472-6882-13-77.

26. Lenucci MS, Cadinu D, Taurino M, Piro G and Dalessandro G. Antioxidant composition in cherry and high-pigment tomato cultivars. Journal Agricultural and Food Chemistry 2006; 54: 2606-2613.

27. Lamien-Meda A, Lamien CE, Compaoré MM, Meda RN, Kiendrebeogo M, Zeba B, et al. Polyphenol content and antioxidant activity of fourteen wild edible fruits from Burkina Faso. Molecules 2008; 13: 581-594.

28. Abdulelah $\mathrm{H}$, Zurainee MN, Hesham MA and Rohela M. Median Lethal Dose, Antimalarial Activity, Phytochemical Screening and Radical Scavenging of Methanolic Languas galanga Rhizome Extract. Molecules 2010;15:8366-8376; doi:10.3390/ molecules15118366: 5-10.
29. Lui KC, Yang SC and Roberts MF. Antimalarial activity of Artemisia annua. Flavonoids from whole plants and cell cultures. Plant cell 1992: 637- 640.

30. Kim YC, Kim H, Wataya Y, Sohn DH, Kang TH, Kim MS, et al. Antimalarial Activity of Lavandulyl Flavanones Isolated From the Roots of Sophora flavescens. Biological Pharmacy Bulletin 2004; 27: 748-750.

31. Monbrison F, Maitrejean M, Latour C, Bugnazet F, Peyron F, Barron D, et al. In Vitro Antimalarial Activity of Flavonoid Derivatives Dehydrosilybin and 8- (1;1)-DMA-kaempferide. Acta Tropica 2006; 97: 102-107.

32. Tasdemir D, Kaiser D, Brun R, Yardley V, Schmidt TJ, Tosun F and Ruedi P. Antitrypanosomal and Antileishmanial Activities of Flavonoids and Their Analogues: In Vitro, In Vivo, Structureactivity Relationship, and Quantitative Structure-activity Relationship Studies. Antimicrobial Agents Chemotherapy 2006; 50: 1352-1364.

\section{Authors Contribution:}

Ettebong E.O - Designed the work, performed the laboratory tests, analysed the data, drafted the manuscript and revised the manuscript. Ubulom P.E - Performed the laboratory tests and assisted in designing the work. Ekpenyong C.E - Contributed to work design and assisted in review of manuscript. Ekong U. S - Contributed to work design. Akpan O.E - Assisted in laboratory tests. Tambari V.D - Assisted in laboratory tests.

Source of Support: Nil, Conflict of Interest: None declared. 